\title{
Constructing institutional performance: a multi-level framing perspective on performance measurement and management
}

DOI:

10.1080/00014788.2018.1507811

\section{Document Version}

Accepted author manuscript

Link to publication record in Manchester Research Explorer

Citation for published version (APA):

Modell, S. (2019). Constructing institutional performance: a multi-level framing perspective on performance measurement and management. Accounting and Business Research, 49(4).

https://doi.org/10.1080/00014788.2018.1507811

Published in:

Accounting and Business Research

\section{Citing this paper}

Please note that where the full-text provided on Manchester Research Explorer is the Author Accepted Manuscript or Proof version this may differ from the final Published version. If citing, it is advised that you check and use the publisher's definitive version.

\section{General rights}

Copyright and moral rights for the publications made accessible in the Research Explorer are retained by the authors and/or other copyright owners and it is a condition of accessing publications that users recognise and abide by the legal requirements associated with these rights.

\section{Takedown policy}

If you believe that this document breaches copyright please refer to the University of Manchester's Takedown Procedures [http://man.ac.uk/04Y6Bo] or contact uml.scholarlycommunications@manchester.ac.uk providing relevant details, so we can investigate your claim.

\section{OPEN ACCESS}




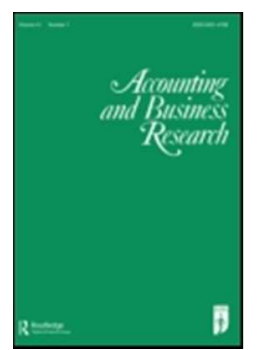

\section{Constructing Institutional Performance: A Multi-Level Framing Perspective on Performance Measurement and Management}

\begin{tabular}{|r|l|}
\hline Journal: & Accounting and Business Research \\
\hline Manuscript ID & ABR-2018-0055.R1 \\
\hline Manuscript Type: & Original Article \\
\hline Keywords - Group 1: & Management accounting \\
\hline Keywords - Group 2: & Discursive logical argument \\
\hline ADD your Keywords: & $\begin{array}{l}\text { Framing, Institutions, Performance measurement and managment, } \\
\text { institutional performance }\end{array}$ \\
\hline \multicolumn{2}{|l}{} \\
\hline
\end{tabular}

SCHOLARONE ${ }^{\text {w }}$

Manuscripts 
Figure 1. The relationships between institutional complexity, PMM practices, framing and institutional performance.

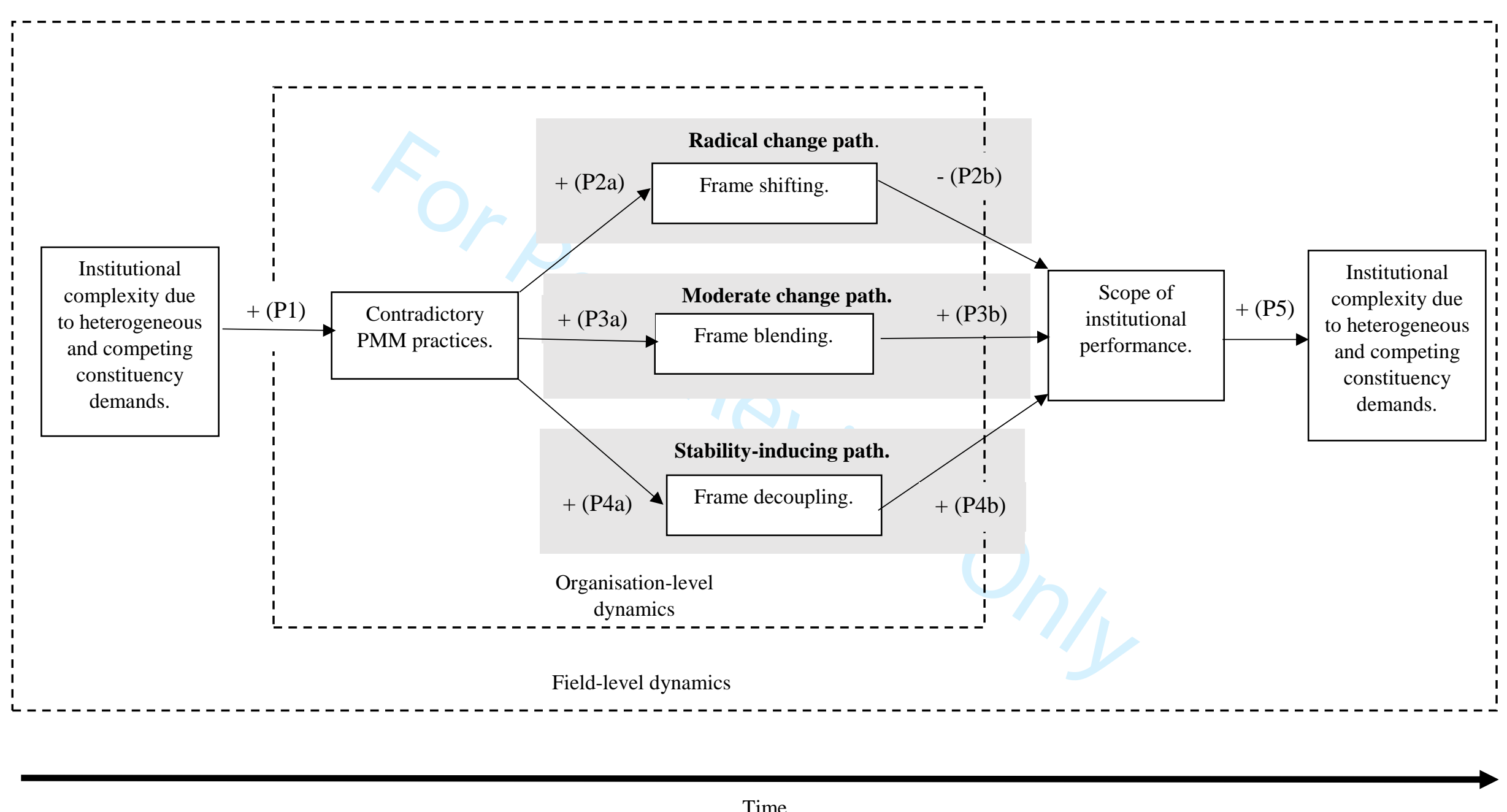




\title{
Constructing Institutional Performance:
}

\section{A Multi-Level Framing Perspective on Performance Measurement and Management}

\begin{abstract}
Research on performance measurement and management (PMM) informed by institutional theory has proliferated over the past two decades. Much of this research has concentrated on the institutional effects on organisational PMM practices and their consequences for organisational behaviour and has only recently started to pay more focussed attention to the effects of such practices on the construction of the very conceptions of performance that come to dominate institutional fields. To further integrative theory development, I pull these strands of research together into an analytical framework pivoting on the concept of institutional performance. Institutional performance is defined as the socially constructed conceptions of organisational performance that become firmly institutionalised as legitimate aspects of achievement in institutional fields. Adopting a multi-level framing perspective, I develop a set of research propositions reflecting how contradictory PMM practices, emerging in response to the institutional complexity attributable to heterogeneous and competing constituency demands, shape such conceptions of performance and how this contributes to reducing or reinforcing institutional complexity over time. I discuss the implications of applying this framework in empirical research and the contributions to institutional research on PMM as well as institutional theory, more generally, that may emerge from such research.
\end{abstract}

Key words: framing, institutions, performance measurement and management. 


\section{Constructing Institutional Performance:}

\section{A Multi-Level Framing Perspective on Performance Measurement and Management}

\section{Introduction}

The issues of performance measurement and management (PMM) have been among the most extensively researched topics in the management accounting literature over the past decades. Much of this research has followed a functionalist approach based on a view of PMM practices as governed by largely pre-defined interests and objectives (Ittner and Larcker 1998, Ferreira and Otley 2009, Franco-Santos et al. 2012). Following the more general insight that accounting plays a powerful, constitutive role in organisations and society (Burchell et al. 1980; Hopwood and Miller 1994, Miller and Power 2013), however, there is also a substantial body of research adopting a view of PMM as a socially constructed phenomenon which is deeply implicated in the shaping of organisational objectives and the meanings associated with the very concept of performance (Townley et al. 2003, Broadbent and Laughlin 2009, Arnaboldi and Azzone 2010, Cooper and Ezzamel 2013, Hall et al. 2015;).

A major stream of work within the latter research genre is the one informed by institutional theory. ${ }^{1}$ This research has grown into a substantial literature which provides valuable insights into how PMM practices are institutionalised and affect organisational behaviour (see Brignall and Modell 2000, Modell 2009, Carlsson-Wall et al. 2016). Yet, as noted by Modell (2009), early research in this area tended to treat the broader institutional environments, or institutional fields, in which organisations are embedded as largely given entities and mainly focussed on the institutional effects on organisational PMM practices. Less attention was being paid to how such practices contribute to the institutionalisation of specific conceptions of performance in organisations and institutional fields. Accounting scholars have recently started to address this limitation (Modell, 2012, Yang and Modell 2013, Chiwamit et al. 2014, 2017, Goretzki et al. 2018, Modell and Yang 2018). However, no systematic effort has yet been made to synthesise research findings into a coherent analytical framework that pays more equal attention to the institutional effects on and of PMM practices and how this

\footnotetext{
${ }^{1}$ In the present paper, institutional theory denotes new (or neo-) institutional sociology, which is the primary strand of institutional thought informing the PMM literature under review (Modell 2009).
} 
contributes to the institutionalisation of different conceptions of performance. Advancing such a framework is important to further integrative theory development regarding how PMM practices affect the evolution of institutional fields.

The issue of how specific conceptions of performance take shape has also been somewhat neglected in the broader management and organisation studies literature based on institutional theory. Whilst institutional theorists have long recognised that the social construction of performance is a key feature of institutional processes (Scott 1987, Meyer and Zucker 1989, Kondra and Hinings 1998, Lounsbury and Ventresca 2003), they have paid little empirical attention to how specific conceptions of performance are institutionalised (Déjean et al. 2004, Lockett et al. 2015). Notions of organisational performance are sometimes included as constitutive elements of institutional logics, denoting the broader ideas and material practices that imbue action in institutional fields with meanings (Thornton 2004, Thornton et al. 2005, Lounsbury 2007, Christiansen and Lounsbury 2013). However, in recent years, concerns have been raised that the concept of institutional logics is overused (Purdy et al. 2018) and that such logics need to be unpacked in greater detail to enhance our understanding of how their constitutive elements work across different levels of analysis (Cloutier and Langley 2013, Zilber 2013, 2017). Focusing on the socially constructed conceptions of performance that evolve in institutional fields is one way of initiating this unpacking. Whilst recognising that such conceptions of performance can be part of specific institutional logics, deeper inquiries into how the former are institutionalised can enhance our understanding of an under-researched topic in institutional theory. Engaging with PMM research evolving in the management accounting literature to this end offers an opportunity to highlight the contributions that sociologically informed accounting research can make to the broader management and organisation studies literature (cf. Miller and Power, 2013).

To advance this research agenda, I develop a framework which explicates how the institutional effects on and of organisational PMM practices are implicated in the construction of institutional performance. I define institutional performance as the socially constructed conceptions of organisational performance that become firmly institutionalised, or taken for granted, as legitimate aspects of achievement in institutional fields. The notion of institutional performance is distinct from that of organisational PMM practices, such as specific goals, performance metrics and evaluation procedures, in that it refers to the more over-riding conceptions of performance, such as efficiency, quality, shareholder value and 
corporate social performance, that are reified into symbols of achievement and therefore bestow a degree of legitimacy on organisations. Organisational goals and performance metrics are often, but not necessarily, concrete manifestations of such over-riding conceptions of performance. However, the notion of institutional performance refers to the more abstract, normative and symbolically charged conceptions of performance espoused by key constituencies ${ }^{2}$ in institutional fields.

According to Kondra and Hinings (1998), the conceptions of performance which are regarded as legitimate by various constituencies often have a strongly constraining effect on organisational behaviour and tend to breed homogeneity within institutional fields. However, institutional theorists have increasingly come to recognise that the prevalence of heterogeneous constituencies with competing demands can be an important source of complexity within institutional fields (Kraatz and Block 2008, Wooten and Hoffman 2008, Greenwood et al. 2011, Vermeulen et al. 2016, Micelotta et al. 2017) and that such complexity influences the conceptions of performance that are institutionalised in such fields (Meyer and Zucker 1989, Lounsbury and Ventresca 2003). Following Meyer and Zucker (1989), I posit that such complexity, and the way it interacts with PMM practices, conditions the scope of institutional performance. Institutional performance is constructed narrowly insofar as the constituencies that make up institutional fields agree on a relatively confined range of performance aspects as being the most legitimate ones. Conversely, institutional performance is constructed more broadly where there is some consensus that a wider range of performance aspects need to be recognised as legitimate symbols of achievement or different constituencies espouse distinct (and often competing) but firmly entrenched conceptions of performance.

To advance more specific explanations of how institutional performance is constructed and contributes to the evolution of institutional fields, I advance a multi-level framing perspective on PMM. The notion of framing is well-established in the broader management and organisation studies literature (Cornelissen and Werner 2014) and is exercising increasing influence on institutional theory. Several institutional theorists have come to see framing, defined as the process through which meanings take shape and produce more or less shared

${ }^{2}$ Such constituencies can be thought of as the key audiences from which organisations need to seek legitimacy (Deephouse and Suchman 2008, Bitektine and Haack 2015) and are typically made up of distinct sets of social actors with competing or overlapping demands on organisations in an institutional field (Kraatz and Block 2008, Wooten and Hoffman 2008). 
conceptions of social realities, as a central aspect of institutionalisation (Lounsbury et al. 2003, Fiss and Zajac 2006, George et al. 2006, Gray et al. 2015, Furnari 2018, Jonsson and Lounsbury 2017, Purdy et al. 2018). I extend this body of research by examining the framing of institutional performance as a process that is both fuelled by institutional complexity, attributable to the prevalence of heterogeneous and competing constituency demands, and that contributes to the maintenance and reduction of such complexity over time. Adopting a multi-level approach, I explicate how pre-existing states of institutional complexity affect organisational PMM practices which, in turn, influence the organisational and field-level processes that frame institutional performance and contribute to upholding varying degrees of complexity. This offers a more holistic and balanced view of the institutional effects on and of PMM practices than that available in prior management accounting research. I discuss how the application of this framework in future empirical work may take institutional research on PMM forward and how such research might also contribute to the more general development of institutional theory.

The remainder of the paper proceeds as follows. I start by elaborating the general theoretical underpinnings of the concept of framing that informs the paper and outlining how it has come to influence institutional research on organisations. This leads to the identification of three discursive strategies, entailing different types of framing, which may influence the emergence of shared meaning systems such as those manifested in the concept of institutional performance. I then advance a propositional framework explicating how PMM practices are implicated in engendering these discursive strategies and how this affects the scope of institutional performance and institutional complexity. This is followed by a discussion of the implications of applying this framework in empirical research and the theoretical contributions that may emerge from such inquiries. I also outline how future research may extend the framework before closing the paper with some brief, concluding remarks.

\section{The Concept of Framing in Institutional Theory}

The literature on frames and framing informing contemporary organisational analyses is very broad and comprises a range of perspectives situating this phenomenon at diverse levels of analysis spanning those of individuals, organisations and institutional fields (Cornelissen and Werner 2014). Most of this literature traces its conception of frames to Goffman's (1974, p. 
21) definition of the concept as the "schemata of interpretation" that enable individuals "to locate, perceive, identify and label" social phenomena and make their actions meaningful. This definition is based on a notion of frames as a fundamentally cognitive construct, operating at the individual level of analysis, but receiving their significance through interactions between human beings and, therefore, forming a basis for the construction of shared meanings. Most recent PMM research explicitly adopting the notions of frames and framing has had a pronounced micro-level focus, exploring how framing processes unfold within individual organisations (e.g., Englund et al. 2013, Yang and Modell 2015, Lorino et al. 2017, Goretzki et al. 2018). By contrast, the present paper answers emerging calls for the development of multi-level approaches that see framing as a phenomenon which evolves within and across organisations whilst being implicated in a recursive interplay with broader, macro-level dynamics within institutional fields (Cornelissen and Werner 2014; Gray et al. 2015, Purdy et al. 2018). This analytical focus is warranted by the emphasis on institutional performance as a field-level construct, which is affected by organisational PMM practices whilst also influencing the propensity for change and stability within institutional fields. It also transcends the conception of framing as a predominantly cognitive process, which has increasingly been criticised for downplaying the socio-political dynamics surrounding this phenomenon (Fiss and Hirsch 2005, Kaplan 2008, Cornelissen and Werner 2014), by drawing attention to how framing processes are related to the politics of meanings in institutional fields.

In advancing a multi-level perspective, that is attentive to the socio-political dimensions of framing, I follow an emerging stream of institutional research (Lounsbury et al. 2003, Chreim 2006, Ansari et al. 2013, Meyer and Höllerer 2010, Werner and Cornelissen 2014, Jonsson and Lounsbury 2017, Furnari 2018) building on the social movement literature and, especially, Snow et al.'s (1986) seminal work on frame alignment. By frame alignment Snow et al. (1986) referred to the extent to which the frames mobilised by particular actors are congruent with the frames enacted by and guiding the actions of other actors in specific social contexts. The notion of frame alignment is akin to that of institutionalisation in that they share a concern with how shared meanings are brought about and form a basis for collective action. However, research on frame alignment has paid more focussed attention to the sociopolitical dynamics through which shared meanings are established and, therefore, constitutes a useful basis for examining the politics of meanings in institutional fields (Benford and Snow 2000, Lounsbury et al. 2003, McAdam and Scott 2005). 
The establishment of shared meanings is particularly problematic where institutional complexity is high. The root cause of such complexity is that institutional fields are often made up of multiple constituencies with competing demands (Kraatz and Block 2008, Wooten and Hoffman 2008, Greenwood et al. 2011, Vermeulen et al. 2016, Micelotta et al. 2017). ${ }^{3}$ The prevalence of such demands can be traced to diverging beliefs, interests and values which, collectively, manifest themselves in a lack of shared meanings across various constituencies. However, organisations develop different strategies for coping with the complexity that follows from such diversity (Greenwood et al., 2011; Oliver, 1991; Vermeulen et al., 2016) and, depending on which strategies dominate in an institutional field, different patterns of institutional change and stability may emerge. Framing processes form an integral part of such strategies by providing a discursive rationale for pursuing different courses of action and may contribute to maintaining or reducing institutional complexity (Lounsbury et al. 2003, Meyer and Höllerer 2010, Ansari et al., 2013, Jonsson and Lounsbury 2017). In the present paper, I distinguish between three discursive strategies frame shifting, frame blending and frame decoupling - with the capacity to affect the institutionalisation of more widely shared meaning systems and, ultimately, institutional complexity.

The first two of these strategies are directly derived from Werner and Cornelissen's (2014) discussion of how framing processes affect institutional change. Frame shifting refers to the mobilisation of "an alternative frame that restructures expectations and experiences and suggests different inferences" (Werner and Cornelissen 2014, p. 1456) to those reinforced by extant frames. Radical attempts at frame shifting typically aim at wholesale replacement of one set of meanings with an alternative set of meanings. Discursive strategies dominated by such frame shifting are likely to be mobilised by actors with a strong interest in disrupting extant frames and creating new frames for the governance of institutional fields (Lounsbury et al. 2003, Jonsson and Lounsbury 2017). Insofar as such shifts become more widely accepted, we may expect emerging frames to enjoy a high degree of frame alignment. Since widespread frame alignment limits the scope of diverging meanings, we may also expect the frames emerging from forceful processes of frame shifting to be relatively robust and uncontested. Over time, such processes are likely to constrain the range of legitimate

\footnotetext{
${ }^{3}$ Some of these authors equate institutional complexity with the prevalence of competing institutional logics (e.g., Greenwood et al 2011, Micelotta et al. 2017). However, there is still an underlying assumption that such logics are underpinned by heterogeneous and competing constituency demands.
} 
constituency demands, challenging emerging meaning systems, and they can therefore contribute to reducing institutional complexity (Lounsbury et al. 2003).

The likelihood of institutional complexity prevailing is higher where institutional change entails a pronounced element of frame blending. Frame blending "is defined as the discursive combination of two separate schemas" (Werner and Cornelissen 2014, p. 1456) and typically results in hybrids of extant and emerging frames. In contrast to frame shifting, frame blending implies a degree of mutual adjustment between the frames enacted by various social actors and entails a more pronounced element of compromise and reconciliation of conflicting meanings. However, since frame blending represents a less complete break with extant frames, it can contain the seeds of continued conflict between constituencies espousing diverging meanings (Meyer and Höllerer 2010, Ansari et al. 2013). Frame blending may therefore be expected to form a less stable outcome of framing processes, entailing less widespread frame alignment around a unified set of meanings, compared to situations where forceful shifts between extant and emerging frames take place and limit the scope of diverging meanings. As a result, the influence of framing on institutional change will be less powerful and is more likely to preserve the heterogeneity of the constituency demands that underpin diverging meanings (Battilana and Dorado 2010, Christiansen and Lounsbury 2013, Pache and Santos 2013, Polzer et al. 2017).

Whilst the notions of frame shifting and blending are concerned with the transformation of institutional fields, institutional complexity can also persist over extended periods of time without seriously disrupting organisations (Reay and Hinings 2005, 2009, Purdy and Gray 2009, Lander et al. 2013). Preserving stability in the face of such complexity poses somewhat different demands on framing processes. One widely documented strategy is to decouple competing frames and thereby prevent overt conflicts from erupting and generating pressures for change (Fiss and Zajac 2006, George et al. 2006, Gray et al. 2015). Hence, it is pertinent to complement the conceptualisation of framing with the notion of frame decoupling, defined as the discursive separation of different meaning systems. ${ }^{4}$ Such frame decoupling may be brought about by efforts to disconnect contentious and potentially conflicting issues, related to competing constituency demands, in organisational discourses. In contrast to frame

\footnotetext{
${ }^{4}$ This form of decoupling is analytically distinct from more structural forms of decoupling, which are typically brought about by functional differentiation in organisations (cf. Meyer and Rowan 1977, Bromley and Powell 2012;). However, the two types of decoupling may be interlinked in that functional differentiation provides opportunities for the discursive separation of frames (see e.g., Brignall and Modell 2000, Carlsson-Wall et al. 2016).
} 
blending, frame decoupling does not entail any efforts to reconcile diverging meanings in an attempt to produce new, hybrid frames, but rather preserves the distinctiveness of different frames. This may enable organisations to balance between competing constituency demands, but it is also likely to exacerbate any attempts to align meanings with a singular frame. Instead, different social actors will continue to enact different frames (Gray et al. 2015). This may, in turn, perpetuate a state of institutional complexity by preserving the integrity of competing constituency demands (Polzer et al. 2017, Furnari 2018).

The above discussion suggests that discursive strategies dominated by different types of framing are likely to emerge depending on whether key actors in an institutional field seek to drive through more or less radical change or preserve stability. Insofar as such actors seek to accomplish radical change, we may expect a strategy of frame shifting to dominate. However, such change dynamics may be tempered by the efforts of other actors to preserve extant frames. This may result in compromises, entailing a degree of frame blending, that moderate, albeit not negate, change initiatives or attempts to preserve stability through frame decoupling. I now turn to examining how these trajectories of institutional development are manifested in relation to PMM practices and how they result in a greater or lesser degree of frame alignment around extant and emerging meaning systems. Using the concept of institutional performance as a key manifestation of such meaning systems, I advance an analytical framework explicating how this concept evolves as an integral part of framing processes fuelled by institutional complexity.

\section{The Framing of Institutional Performance}

The framework advanced below seeks to capture the role of PMM practices in the dynamic and recursive interplay between pre-existing states of institutional complexity and the framing processes which affect the scope of institutional performance and maintain or reduce such complexity. The starting point for this discussion is that institutional complexity, originating in heterogeneous and competing constituency demands, breeds more or less contradictory PMM practices within organisations. Performance measurement and management practices are said to be contradictory insofar as they encompass conflicting goals and performance metrics which are difficult, though not necessarily impossible, to reconcile in a logically coherent way and which can heighten socio-political tensions in 
organisations (Brignall and Modell 2000, Modell 2001). The use of such practices will, in turn, foster discursive strategies dominated by either frame shifting, blending or decoupling insofar as various conceptions of performance are concerned. As such framing processes gain traction within organisations and institutional fields, a varying degree of frame alignment will be produced and affect the scope of institutional performance. Over time, the framing of institutional performance is also seen as affecting institutional complexity by reducing or reinforcing the salience of heterogeneous and competing constituency demands. Figure 1 summarises the propositional framework reflecting this interplay between institutional complexity, PMM practices, framing and institutional performance.

Insert Figure 1 here!

\subsection{The impact of institutional complexity on organisational PMM practices}

The notion that institutional complexity, originating in heterogeneous and competing constituency demands, can be a source of contradictory PMM practices is well-documented in prior research. Building on the more general insight that such complexity often creates contradictions and tensions in organisations (Meyer and Rowan 1977, Powell 1988, Seo and Creed 2002), Brignall and Modell (2000) advanced an analytical framework explicating how the multiplicity of competing constituency demands influences organisational PMM practices. Situating their framework in the context of market-orientated reforms in the public sector, they discussed how such reforms often add a layer of complexity in institutional fields by amplifying the competing demands of market actors, fund-granting bodies and professional service providers. As individual organisations respond to such demands, the prevalence of conflicting goals and performance metrics was predicted to increase. Examples of such conflicts include the difficulties in reconciling performance information used for the purpose of market-based pricing with that required for financial resource allocation and professional quality assurance. Empirical evidence of similar conflicts emerging in response to competing constituency demands has been found across a variety of institutional fields, 
including public health care (Modell 2001, Chang, 2006, Østergren 2006, Conrad and Uslu, 2012, Kelly et al. 2015), higher education (Modell 2003, 2005, Boitier and Riviere 2013), central government (Modell et al. 2007, Modell and Wiesel 2008) and state-owned enterprises (Siti-Nabiha and Scapens 2005, Sharma et al. 2010, Sundin et al. 2010).

Support for the conjecture that institutional complexity has a major impact on the evolution of contradictory PMM practices can also be summoned from research that relates the development of such practices to institutional logics (Rautiainen and Järvenpää, 2012, Schäffer et al. 2015, Carlsson-Wall et al. 2016, Beer and Micheli 2017, Rautiainen et al. 2017). Much of this research shows that conflicting constituency demands, that underpin competing logics, breed contradictory PMM practices. However, it also underlines how the growing dominance of specific constituencies leads to increasing emphasis being placed on a particular set of goals and performance metrics at the expense of a broader range of conflicting goals and metrics. Evidence of such a pattern has been found in various parts of the public sector, including local government (Rautiainen and Järvenpää 2012) and law enforcement (Rautiainen et al. 2017), where growing political demands for cost containment privilege a narrow set of efficiency-centred goals and performance metrics over the ones linked to a broader range of competing constituency demands. Not surprisingly, perhaps, Schäffer et al. (2015) show that such tendencies to confine PMM practices to a single set of narrowly focussed, financial goals and performance metrics can be even more pronounced in private sector, for-profit organisations exposed to increasing demands for returns to shareholders. Examining the role of such practices in a German firm, that underwent a shift from family to private equity ownership, they observed how this development suppressed extant PMM practices recognising a broader range of constituency demands. However, as demonstrated by Carlsson-Wall et al. (2016), such privileging of one set of constituency demands over others is not an inevitable outcome in private sector organisations exposed to financial performance pressures. Rather, in their field study of a private sector sports organisation, they observed how two firmly entrenched institutional logics, which were espoused by two distinct constituencies (sports enthusiasts and shareholders), caused different organisational actors to use two separate and often conflicting sets of performance metrics centred on sports- and business-related concerns, respectively.

Taken together, the research reviewed above suggests that institutional complexity, originating in heterogeneous and competing constituency demands, is an important 
antecedent of contradictory PMM practices in organisations. Unless one set of demands becomes dominant over time and reduces the salience of competing demands, organisations are likely to emphasise a broad range of conflicting goals and performance metrics. Conversely, where there is greater consistency between constituency demands, the propensity of organisations to devise conflicting goals and performance metrics may be expected to decline. This leads to the first research proposition:

\section{Proposition 1}

The higher the level of institutional complexity due to heterogeneous and competing constituency demands in an institutional field, the greater the use of contradictory PMM practices in organisations within that field.

\subsection{Contradictory PMM practices and the framing of institutional performance}

Faced with contradictory PMM practices, organisations may pursue a range of alternative, discursive strategies. Consistent with the general perspective on framing advanced above, these strategies are likely to differ depending on whether individual organisations use PMM practices as a means of pursuing more or less radical change or seek to maintain stability. Prior research shows that institutional contradictions can be a powerful source of change, because they provide opportunities for critics to question the status quo and to establish a rallying point for the mobilisation of collective action (Seo and Creed 2002, Greenwood and Suddaby 2006, Hiebl 2018), but also suggests that such change dynamics may be tempered as organisations seek to conceal contradictions and avoid disruptive conflicts (Powell 1988, Oliver 1991, Bromley and Powell, 2012). I extend this line of argument by discussing how discursive strategies dominated by either frame shifting, blending or decoupling emerge from the use of contradictory PMM practices and affect the scope of institutional performance. In doing so, I identify three distinct paths of institutional development, characterised by varying degrees of change and stability, and discuss how each path generates varying degrees of frame alignment around broader or narrower notions of institutional performance (see Figure $1)$.

\subsubsection{The radical change path}


Radical change initiatives emanating from contradictory PMM practices may be triggered by the realisation that such practices are indicative of more deep-seated conflicts between incompatible demands which can be exploited by powerful organisational actors with an interest in pursuing such change initiatives. As noted by Englund et al. (2013), the ambiguity often associated with conflicting goals and performance metrics can heighten the reflexivity of managers and enhance their awareness of the need to break with institutionalised practices and change their frames accordingly. Contradictory PMM practices may also be harnessed as a means of convincing a broader range of organisational actors of the need for radical change and this is likely to reinforce the tendencies towards frame shifting. Two relatively recent examples of changes in the discourse surrounding organisational PMM practices illustrate how such processes of frame shifting can be initiated.

The first example can be found in the increasing pursuit of shareholder value creation in listed companies and how this has been buttressed by discourses promoting novel, financial performance metrics (e.g., Economic Value Added) as a distinct alternative to a broader set of conflicting goals and performance metrics that allegedly detract from shareholder value maximisation (Ezzanel et al. 2008, Kraus and Strömsten 2012, Chiwamit et al. 2014, 2017, Yang and Modell, 2015). As demonstrated by Chiwamit et al. (2014, 2017), this type of frame shifting has formed an integral part of the global shareholder value movement and has been mobilised by actors with strongly vested interests in privatising state-owned enterprises in emerging economies. The use of aggregate, financial performance metrics, such as Economic Value Added, has here been presented as a means of addressing the alleged inefficiencies that follow from the traditional use of PMM practices based on a broader range of conflicting economic, political and social goals. Although this shift has often been tempered by resistance, stemming from the continued need for state-owned enterprises to meet the demands of a wider range of constituencies, it has been found to be especially pronounced in enterprises where managers seek to harness the emerging, shareholder value discourse to justify radical change (Yang and Modell 2015, Chiwamit et al. 2017). Similarly, Kraus and Strömsten (2012) provide evidence of how frame shifting, favouring a small set of financial performance indicators over a broader range of conflicting performance metrics, was used to legitimise the stock market listing of a private sector company to managers as well as a broader range of capital market actors. 
The second example of how contradictory PMM practices foster discursive strategies dominated by frame shifting originates in the efforts to re-orient PMM practices in the public sector from a heavy emphasis on outputs to outcomes as part of broader reforms aimed at replacing market-based governance mechanisms with more network-like modes of governance (Catasús and Grönlund 2005, Modell et al. 2007, Watkins and Arrington 2007, Cuganesan and Lacey 2011, Wiesel and Modell 2014, ter Bogt et al., 2015). The discourse surrounding such reforms has often entailed pronounced criticisms of the plethora of conflicting goals and performance metrics of a short-term nature that often prevail in the public sector and which allegedly hamper the pursuit of a more unified, or joined-up, conception of the long-term effectiveness of public services. For instance, Watkins and Arrington (2007) show how such criticisms formed an integral part of the promotion of the National Performance Review in the US and how the concomitant framing efforts came to pivot on the need for federal government agencies to radically alter their PMM practices to place greater emphasis on the outcomes for the ultimate beneficiaries of public services. Similarly, Cuganesan and Lacey (2011) report that the use of conflicting performance metrics, detracting from a joined-up approach to service delivery, created a powerful impetus for the advancement of outcome-focussed performance metrics in an Australian law enforcement agency. This change initiative was framed as a critical step, enabling the organisation to make better informed cost-benefit decisions, that would radically enhance the effectiveness of law enforcement.

The studies reviewed above support the more general conjecture that institutional contradictions can be an important source of radical change in organisations (Seo and Creed 2002, Greenwood and Suddaby 2006, Hiebl 2018). More specifically, they suggest that contradictory PMM practices, made up of a range of conflicting goals and performance metrics, can reinforce such change dynamics by fuelling framing processes that call for radical shifts in the meanings attributed to organisational performance. Hence:

\section{Proposition 2a}

In organisations pursuing radical change, contradictory PMM practices will promote discursive strategies dominated by frame shifting insofar as the conception of performance is concerned. 
As argued earlier in this paper, frame shifting can be a potentially powerful means of frame alignment insofar as it limits the scope of diverging meanings and establishes consensus around new sets of meanings. As demonstrated by Lorino et al. (2017), however, the prevalence of contradictory PMM practices does not always produce such frame alignment and may instead form a basis for resistance to change. In their field study of buyer-supplier relationships in the French retail sector, they showed how buyers exploited conflicting performance information, originating in different PMM practices, to resist the efforts of suppliers to frame such relationships in more collaborative terms in an attempt to maintain their bargaining power. To overcome such resistance and produce radical change a considerable narrowing of what counts as legitimate conceptions of performance, that reduces the possibilities of various actors to mobilise diverging conceptions of performance, may be necessary. Modell (2012) shows how processes of frame alignment, following such a trajectory, unfolded in a Swedish central government agency. Having relied on PMM practices which promoted a very broad, but unfocused, conception of performance, the agency replaced it with a much narrower framing of what was seen as strategically relevant performance aspects. This frame shifting reinforced the managerial consensus around a more restricted conception of performance, centred on a small number of easily measurable performance aspects, and reduced resistance to the emerging organisational strategy. Similar findings were reported by Ligonie (2018) in a study of the implementation of corporate social responsibility in a private sector gambling company. Whilst this initiative initially generated considerable ambiguity and conflict, centred on how corporate social performance should be conceptualised, resistance to change was largely overcome once managers' frames were aligned with narrower and more easily measurable conceptions of social performance.

Insofar as processes of frame shifting and frame alignment, such as those observed above, are extended across a wider range of organisations within institutional fields, we may expect new, but relatively narrow notions of institutional performance to emerge. An illustrative example of how such field-level processes may unfold can be found in the institutionalisation of new conceptions of corporate social performance in the field of socially responsible investment in France (Déjean et al. 2004, Arjaliès 2010, Giamporcaro and Gond 2016). As demonstrated by Déjean et al. (2004), it was only by shifting the frames surrounding the initially broad and ill-defined notion of corporate social performance and making it measurable that the organisation promoting a new standard for this purpose could start to legitimise socially responsible investment practices and produce radical change. This implied 
a significant narrowing of corporate social performance, which helped to align the frames of other capital markets actors with the new standard. This facilitated the diffusion of the new standard across other organisations in the field of socially responsible investment and reinforced the institutionalisation of the emerging conception of performance. Subsequent studies have shown that this conception of corporate social performance has been firmly institutionalised and how this has promoted the growth in socially responsible investment in France (Arjaliès 2010, Giamporcaro and Gond 2016).

The above observations suggest that strategies of frame shifting, aimed at mobilising radical change, are often accompanied by a narrowing of the conception of performance and that this can produce widespread frame alignment. It is, of course, possible to envisage situations where frame shifting is mobilised to replace narrow conceptions of performance with broader and more inclusive ones. However, this increases the likelihood of multiple, conflicting interpretations emerging and is likely to reduce the possibilities of frame alignment around a unified set of meanings. This is, in turn, likely to moderate change dynamics. Several field studies show that the introduction of broadly based PMM practices, such as balanced scorecards, fails to produce widespread agreement about what should count as legitimate conceptions of performance (Adolfsson and Wikström 2007, Arnaboldi and Azzone 2010, Qu and Cooper 2011, Sutheewasinnon et al. 2016) or require a considerable narrowing of such conceptions to produce a degree of frame alignment and forceful, collective action (Edenius and Hasselbladh 2002, Länsiluoto et al. 2013). A major reason for such problems seems to be the difficulties in unifying the meanings of various actors around novel conceptions of performance when the PMM practices that underpin them allow for a wider range of conflicting interpretations. For instance, Adolfsson and Wikström (2007) demonstrate how the introduction of a balanced scorecard fostered a multitude of diverging, local interpretations of organisational performance rather than producing a more unified frame serving as a rallying point for radical change. By contrast, Länsiluoto et al. (2013) found that such effects may be mitigated by framing processes which produce widespread agreement as to what constitutes key, but relatively narrow, conceptions of performance even though a wider set of performance metrics are in use. Others have argued that PMM practices such as balanced scorecards only reduce the ambiguity of meanings and produce forceful action once the conceptions of performance embedded in them are rendered more selective (Edenius and Hasselbladh 2002, Modell 2004, Catasus et al., 2007). Shifts in frames towards narrow conceptions of performance are thus more likely to produce strong frame alignment and 
elevate such conceptions to the status of institutional performance, supporting radical change, than are shifts towards broader conceptions of performance. Hence:

Proposition $2 b$

Strategies of frame shifting, engendering radical change in organisations and institutional fields, will construct institutional performance in narrow terms.

\subsubsection{The moderate change path}

Radical change initiatives, entailing pronounced frame shifting, often encounter resistance and are tempered by framing processes that preserve a degree of continuity in meaning systems (Chreim 2006; Kaplan 2008, Meyer and Höllerer 2010). As noted above, contradictory PMM practices can be a source of such resistance insofar as they provide a basis for challenging attempts at frame shifting (Lorino et al. 2017). However, this does not necessarily imply that change dynamics are completely negated. Instead, organisations may respond by moderating change initiatives and engaging in a pronounced element of frame blending aimed at reconciling extant and emerging frames. Evidence of how contradictory PMM practices are implicated in such framing processes can be found in the emergence of a stronger emphasis on shareholder value creation in Chinese state-owned enterprises (Yang and Modell 2015, Modell and Yang 2018). Radical proposals for such changes by actors, representing capital market interests, have here been resisted since such changes would disrupt the delicate balance between conflicting economic, political and social goals espoused by a broader range of constituencies. Rather than remaining static, however, the field has been dominated by discourses entailing a pronounced element of frame blending to imbue the use of novel, shareholder-focussed performance metrics, such as Economic Value Added, with meanings that are congruent with more long-standing PMM practices (Modell and Yang 2018). Instead of using such metrics to maximise shareholder value, this frame blending has led state-owned enterprises to reconcile the increasing pursuit of financial returns with meanings originating in China's communist past, such as the need to maintain a high degree of political and social cohesiveness (Yang and Modell 2015, Dai et al. 2017, Bhimani et al. 2018). This has moderated, albeit not negated, the pressures for change and has contributed to overcome some of the resistance to shareholder value creation. For instance, Yang and Modell (2015) found that an organisation-specific change initiative, which was initially 
characterised by a pronounced element of frame shifting, was gradually superseded by managerial discourses dominated by frame blending to deal with resistance to change. Similar findings have been reported in local government (Yang and Modell 2013), not-forprofit (Beer and Micheli 2017) and non-governmental organisations (Chenhall et al. 2013), where the existence of conflicting goals and performance metrics have prompted managers to reconcile extant and emerging performance discourses rather than pursuing radical change. Hence:

\section{Proposition 3a}

In organisations pursuing moderate change, contradictory PMM practices will promote discursive strategies dominated by frame blending insofar as the conception of performance is concerned.

Some of the studies cited above provide insights into how processes of frame blending produce pronounced, albeit relatively fragile, compromises that promote relatively broad conceptions of performance. For instance, Yang and Modell (2013) show how the efforts of a Chinese local government organisation to reconcile the meanings embedded in extant and emerging PMM practices produced a broad conception of organisational performance that appealed to a wide range of constituencies. However, the need to attend to multiple constituencies moderated the underlying pressures for change and the frame alignment around the emerging, hybrid conception of performance only proved viable as long as the organisation was able to uphold a reasonable balance between competing constituency demands. Similarly, Chenhall et al. (2013) report that the managers of a non-governmental organisation struggled to resolve conflicts due to incomplete and fragile compromises between different performance discourses and that this perpetuated a relatively broad conception of performance in the organisation. These findings support the argument that frame blending represents an incomplete means of conflict resolution and is unlikely to result in frame alignment around a narrower set of meanings (Meyer and Höllerer 2010, Ansari et al. 2013). However, this does not mean that frame blending necessarily produces little more than temporary change and, in the long term, reinforces the status quo. As demonstrated by Modell and Yang's (2018) field-level analysis of the development of PMM practices in Chinese state-owned enterprises, sustained frame blending can, indeed, generate relatively robust frame alignment around new, but relatively broad, conceptions of performance. 
Similar observations showing how increasing consensus, or frame alignment, around new and relatively broad conceptions of performance can be produced in institutional fields, have been made in relation to "third stream activities" in UK higher education (Lockett et al. 2015; Power 2015). These activities have aimed at broadening the scope of university operations beyond research and teaching in order to enhance the societal impact of universities. The UK government initially sought to promote such activities by narrowing the definition of impact to a few, easily measurable performance aspects focussed on financial returns. However, this relatively radical change initiative was resisted by universities and other constituencies. In mobilising such resistance, universities deliberately sought to broaden the discourse around impact by pointing towards the need to include a wider range of performance aspects and, over time, a compromise, reconciling the notion of impact with more long-standing conceptions of university performance, emerged (see Lockett et al. 2015). This frame blending has imbued the notion of impact, diffusing across universities, with meanings that have become more widely accepted by key constituencies in the field of higher education and has contributed to institutionalise a relatively broad conception of performance (Lockett et al. 2015, Power 2015). This shows how an emerging strategy of frame blending, that broadens institutional performance, can gradually produce more widespread frame alignment and a degree of change in institutional fields without radically altering extant meaning systems. Hence:

Proposition $3 b$

Strategies of frame blending, engendering moderate change in organisations and institutional fields, will construct institutional performance in broad terms.

\subsubsection{The stability-inducing path}

Whilst the discussion above shows how the framing of institutional performance may be implicated in instigating more or less radical change processes, contradictory PMM practices may also prompt discursive strategies dominated by frame decoupling in an attempt to preserve the status quo. Such frame decoupling is distinct from frame shifting and blending in that it neither aims at replacing nor reconciling different conceptions of performance, but rather seeks to preserve their distinctiveness in order to avoid conflicts between competing constituency demands. Brignall and Modell (2000) argue that organisations may pursue such 


\section{Proposition 4a}

In organisations seeking to maintain stability, contradictory PMM practices will promote discursive strategies dominated by frame decoupling insofar as the conception of performance is concerned.

Since frame decoupling typically aims at preserving the distinctiveness of diverse conceptions of performance, we may expect such a strategy to construct institutional performance in relatively broad terms. Rather than aligning the frames of various 
constituencies around a unified frame, several competing and firmly entrenched conceptions of performance are likely to continue to co-exist. An illustrative example of such a development can be found in Modell's $(2003,2005)$ study of the evolution of PMM practices in Swedish higher education. Modell (2003) showed how an initial attempt by the government to integrate notions of efficient resource utilisation with those of quality of education into a unified set of goals and performance metrics failed due to forceful resistance from a range of constituencies. This resulted in the institutionalisation of separate PMM practices for managing resource allocation and quality which, to a large extent, were mimicked by individual universities. This enabled universities to decouple the discourses related to efficiency and quality and avoid disruptive conflicts. As illustrated by Modell (2005), it also enabled the regulatory agency in charge of quality management to align other constituencies (e.g., academics and students) with its framing of the notion of quality, whilst the government continued to frame issues of efficiency as separable from the quality of education. For an extended period of time, two separate, yet firmly entrenched, conceptions of performance, espoused by diverse constituencies, were thus maintained at multiple levels of the field of Swedish higher education. This allowed universities to deflect pressures for change despite emerging criticisms of their PMM practices.

These observations reinforce the argument that frame decoupling is a viable discursive strategy for preserving stability in organisations and institutional fields (Gray et al. 2015) and that this is likely to construct institutional performance in relatively broad terms. However, as a strategy for deflecting pressures for change, frame decoupling is potentially vulnerable and only likely to fill such a role as long as particular actors, with a strong interest in pursuing radical change, are unaware of or unable to challenge the resultant plurality of meanings (Powell 1988, Pache and Santos 2013). As we have seen above, such radical change initiatives are likely to entail a pronounced element of frame shifting which serves to narrow institutional performance. Over time, discourses dominated by frame decoupling may thus give way to ones dominated by frame shifting, but as long as such pressures for change can be avoided the following proposition may be expected to hold:

\section{Proposition $4 b$}

Strategies of frame decoupling, inducing stability in organisations and institutional fields, will construct institutional performance in broad terms. 


\subsection{The impact of institutional performance on institutional complexity}

Turning, finally, to the influence of institutional performance on institutional complexity, there are good reasons for expecting the scope of the former notion to have a major impact on the salience of heterogeneous and competing constituency demands. As noted in the foregoing, framing processes that allow a broader range of meanings to prevail are likely preserve a relatively high degree of institutional complexity attributable to such demands (Battilana and Dorado 2010, Christiansen and Lounsbury 2013, Pache and Santos 2013, Polzer et al. 2017). However, where framing processes suppress the prevalence of diverging meanings, as is the case when the scope of institutional performance is narrowed, we may expect institutional complexity to be reduced. For instance, Thornton (2004) shows how the rise of international corporations in the field of higher education publishing brought about a relatively radical shift in corporate strategies away from concerns with serving students and broader academic communities to strategies emphasising the primacy of capital market interests. This shift was underpinned by the replacement of an institutional logic, entailing a relatively broad conception of performance centred on educational value, by one that was dominated by more restricted notions of stock market performance as a source of legitimacy. Extending these findings to a French publishing firm, Le Theule and Lupu (2016) demonstrate how this development was reinforced by organisational discourses focussed around a limited set of financial performance aspects and how this contributed to marginalise the broader constituency demands traditionally served by publishing companies. By narrowing the conception of legitimate performance to financial returns, the demands of authors, editors and readers were found to be jeopardised whilst those of shareholders were elevated to a more supreme position than had previously been the case. Even though this did not immediately eliminate the prevalence of competing constituency demands, it fostered a development whereby the complexity associated with such demands was increasingly suppressed in organisational decision making. Insofar as such attempts to suppress competing constituency demands diffuse across organisations within institutional fields and reinforce the dominance of particular constituencies at the expense of others, we may expect institutional complexity to decline.

Contrary evidence, showing how broader notions of institutional performance contribute to uphold institutional complexity, can primarily be found in fields where competing yet firmly 
entrenched conceptions of performance emerge and continue to co-exist over extended periods of time. Research in the field of health care has demonstrated how different institutional logics, entailing diverging conceptions of performance centred on businessorientated concerns with efficiency and professional standards of quality of care, have been implicated in entrenching the demands of competing constituencies such as managers and physicians (Scott et al. 2000, Reay and Hinings 2005, 2009). Similarly, in his study of the US mutual funds industry, Lounsbury (2007) documented how a novel conception of performance, pivoting on the aggressive pursuit of short-term financial returns, was institutionalised and formed a centre piece of a new institutional logic competing with the previously dominant logic, centred on a more conservative conception of investment performance. Over time, mutual funds tended to primarily pursue one or the other of these conceptions of performance. This enabled the industry to serve a broader range of constituencies with competing investment preferences, but also created a more complex institutional environment. This shows how the broadening of institutional performance can reinforce the salience of heterogeneous and competing constituency demands. Hence the final research proposition:

\section{Proposition 5}

The broader the scope of institutional performance, the higher the level of institutional complexity due to heterogeneous and competing constituency demands in institutional fields.

\section{Discussion}

The analytical framework advanced above provides a starting point for examining how institutional performance is constructed and influences the evolution of institutional fields. In doing so, it fleshes out general institutional arguments regarding the relationship between institutional complexity, framing and the institutionalisation of more widely shared meaning systems with specific reference to the role of organisational PMM practices. It also provides a relatively holistic, multi-level view of how such practices condition framing processes and how this influences institutional performance. To nurture such a multi-level perspective, empirical research testing and extending the framework should ideally take the form of longitudinal inquiries exploring how institutional performance and varying degrees of institutional complexity evolve at the field level whilst being implicated in a recursive 
interplay with the framing processes unfolding within and across organisations. It is only by exploring such recursive, multi-level dynamics that we may arrive at a deeper understanding of what promotes and detracts from processes of frame alignment within institutional fields and how such processes shape various conceptions of performance. Such research will invariably need to entail a pronounced qualitative element. This is necessary to not only track the complex and often contested processes through which a greater or lesser degree of frame alignment is brought about (Benford and Snow 2000, Snow et al. 1986), but also to nurture an in-depth understanding of the meanings attributed to the notion of performance and how they evolve over time. However, researchers can complement such analyses with quantitative inquiries, using survey or archival data, to explore the prevalence of various frames across organisations within the field under examination and whether this changes over time and reflects a degree of frame alignment around extant and emerging conceptions of performance. Whilst the research questions used to investigate such processes need to be adapted to the fields in which research is conducted, I offer some examples of general questions that can serve as a starting point for operationalising the propositions advanced in this paper in the Appendix.

Although multi-level analyses, such as that outlined above, are beginning to gain prominence in institutional research (Dillard et al. 2004, Hopper and Major 2007, Purdy and Gray 2009, Smets et al. 2012, Moore 2013, Bitektine and Haack 2015), they are still relatively rare in the PMM literature. Insofar as researchers have considered how PMM practices evolve across different levels of institutional fields, they have mainly explored the development of fieldlevel practices and how individual organisations adapt such practices (Modell et al. 2007, Conrad and Uslu, 2012, Boitier and Riviere 2013, Kelly et al. 2015). By contrast, by drawing attention to the recursive relationships between these levels of analysis, the framework advanced in this paper invites research into how individual organisations influence field-level practices. Such research can make important contributions to our understanding of how organisational PMM practices not only evolve in response to changes in the broader institutional environment, but also how they come to have wider institutional effects and shape such environments over time. It would also seem worthwhile to extend such research to encompass theoretical comparisons across institutional fields. Comparative research across institutional fields is still scarce (Micelotta et al. 2017, Furnari, 2018) and has only started to feature in the PMM literature (Chiwamit et al. 2014, Rautiainen et al. 2017). However, such research has considerable potential to further systematic theory development regarding how 
differences in broader field conditions, such as variations in institutional complexity, influence the framing of institutional performance.

Whilst empirical studies following the lines suggested above can take institutional research on PMM forward, such research may also make more general contributions to institutional theory. By focussing on how PMM practices are implicated in the framing of institutional performance, I have highlighted a set of analytical categories that have been somewhat neglected in institutional theory. Extending this line of argument, I want to draw attention to two distinct contributions to institutional theory that may emerge from further, empirical research that pays more focussed attention to the framing of institutional performance.

First, as noted in the introduction, the relative neglect of how socially constructed conceptions of performance take shape in institutional theory is partly due to such conceptions being subsumed under broader analytical concepts such as institutional logics. However, by examining how the framing of institutional performance interacts with the other constitutive elements that make up diverse institutional logics, researchers can start to unpack the processes through which such logics are reproduced or transformed. As noted by Schneiberg (2007), even the most settled paths of institutional development, underpinned by firmly entrenched logics, are potentially open to disruption and this may lead the constitutive elements of competing logics to be selectively combined into essentially "new", contextspecific logics. Processes of frame blending, that reconcile notions of performance derived from different institutional logics, can fuel such combinations. However, by drawing attention to the possibilities of frame shifting and decoupling, the framework advanced in this paper can also provide a starting point for examining the processes of reproduction and transformation that underpin other types of institutional development. Radical frame shifting, which replaces one conception of performance with another conception of performance, may be expected to fuel processes whereby extant logics are challenged and replaced in toto by alternative logics. By contrast, frame decoupling is likely to negate such change dynamics and will perhaps contribute to a situation, where co-existing, competing logics continue to be reproduced and imbue institutional fields with a degree of stability. By paying more focussed attention to how the framing of institutional performance, evolving along these trajectories, interacts with other constitutive elements of institutional logics, researchers can avoid the pitfall of conceiving of such logics as readily available and monolithic entities (Cloutier and Langley 2013, Zilber 2013, 2017). The concept of framing has a distinct advantage over that 
of institutional logics in that it is more open-ended and sensitive to the context-specific meanings that evolve in institutional fields (Purdy et al. 2018). This enhances its usefulness across a wider range of contexts and frees researchers from the need to choose from a limited set of pre-defined logics as analytical archetypes in making sense of how institutional fields evolve.

Second, more focussed attention to institutional performance as a socially constructed phenomenon, evolving through diverse framing processes, may guard against the temptation to reduce the analysis of performance to essentially functionalist questions of whether specific, institutionalised practices improve organisational performance. According to David and Bitektine (2009), the lack of interest in such questions in institutional theory has limited its appeal to especially managerial audiences and has reduced its impact on organisational practices. However, rectifying this limitation by examining the effects of institutionalised practices on "profit, return on investment, or other standard measures of performance" (David and Bitektine 2009, p. 170), whilst assuming that such measures are universally valid across institutional fields, would go against the ontological roots of institutional theory as a perspective that is firmly grounded in social constructivist thought (Meyer and Rowan 1977, DiMaggio and Powell 1983). As I hope to have demonstrated in this paper, the conceptions of performance that become more widely accepted as legitimate aspects of achievement are more or less malleable and specific to institutional fields. Hence, to enhance our understanding of how particular conceptions of performance come to matter, researchers need to delve into the field-specific processes through which key constituencies come to agree on why certain conceptions of performance are of paramount importance whilst others are of lesser significance. By examining how such processes buttress some constituency demands and marginalise others, researchers can also generate valuable insights into how the social construction of performance creates "winners" and "losers" in institutional fields. Research on institutional performance may thus raise more profound questions about how institutional processes affect notions of social equity and justice than has been customary in institutional theory (Zald and Lounsbury 2010, Modell 2015, Lok 2018). This provides a counterpoint to functionalist calls for making institutional theory more useful to narrow, managerial audiences (e.g., David and Bitektine, 2009) and may enable institutional theorists to engage in debates about how their work has broader, societal relevance (Modell 2014). 
Whilst the analytical framework advanced in this paper provides a starting point for examining how institutional performance is constructed within and across institutional fields, future research may also extend it in at least two ways. A first, fruitful line of extension would be to not only examine how different framing processes shape the scope of institutional performance, but also explore how different levels of performance affect the evolution of institutional fields. Although the latter issue has received less attention in prior research, Kondra and Hinings (1998) argue that the relative position of organisations along the conceptions of performance that are deemed legitimate in institutional fields is intimately connected to the diversity observed in such fields. In fields where there is greater tolerance of diverse forms of organisational behaviour, the levels of performance may be expected to vary much more than in fields where only particular forms of behaviour are sanctioned by key constituencies. A limitation of Kondra and Hinings' (1998) argument, however, is that they assume that only one, or a very confined range of performance aspects, dominate institutional fields. As argued in this paper, such a situation may emerge where institutional performance is constructed narrowly, but it is not the case where such performance is broadened. Hence, it is relevant to pursue further empirical research into how the scope of institutional performance interacts with the levels of performance enjoyed by different organisations and how this interplay shapes institutional fields. Exploring this issue is particularly pertinent in fields where a strong element of relative performance evaluation, in the form of league tables and rankings, prevails. Whilst sociologically informed research on the effects of such PMM practices has grown into a substantial literature (e.g., Llewellyn and Northcott 2005, Espeland and Sauder 2007, Kornberger and Carter 2010), it is only recently that researchers have started to explore the interplay between multiple rankings constructed around distinct conceptions of performance (Pollock et al. 2018).

The second line of extension concerns the process through which variations in framing emerge in institutional fields and how such variations are either perpetuated or suppressed over time. The framework advanced in this paper posits that the scope of institutional performance will vary depending on whether the framing processes emerging in institutional fields are dominated by frame shifting, blending or decoupling. However, it recognises that individual organisations may devise different discursive strategies, dominated by one of these types of framing, depending on whether they have an interest in pursuing varying degrees of change or maintaining stability. Exploring the issue of why organisations within the same institutional field sometimes follow different strategies may shed further light on how 
accounting is implicated in generating variations in such fields (cf. Lounsbury 2008, Ezzamel et al. 2012, Arena and Jeppesen 2016, Chiwamit et al. 2017). Insofar as such variations persist over time, it is conceivable that a relatively broad range of competing conceptions of performance will prevail and that institutional fields will fail to coalesce around more widely shared meanings. As argued in this paper, this is one way through which broad notions of institutional performance can be maintained. However, further research is required into how such plurality of meanings, which may give rise to a state of field fragmentation (Kraatz and Block 2008, Furnari 2018), are perpetuated or give way to forces that foster a degree of frame alignment around shared conceptions of performance. Of specific interest in this regard are the strategies that some organisations, with an interest in changing such states of affairs, devise to create a shared set of meanings and how other organisations within the same field respond to such pressures for conformity. Such attempts at frame alignment can give rise to inter-organisational power struggles, which have not been explicitly theorised in the framework advanced in this paper. Exploring how such power struggles unfold can deepen our insights into the politics of meanings, which lies at the heart of the concept of frame alignment, and can enhance our understanding of the processes through which institutional performance is constructed.

\section{Concluding Remarks}

This paper has sought to advance theory development concerning the role of organisational PMM practices in institutional processes by providing a more holistic depiction of how such practices not only evolve in response to institutional field conditions, but also have wider institutional effects that shape such conditions over time. Whilst grounded in a broader research tradition, emphasising that accounting fills a constitutive role in organisations and society (Burchell et al., 1980; Hopwood and Miller, 1994; Miller and Power, 2013), the analytical framework advanced in this paper has fleshed out this general idea by showing how contradictory PMM practices can trigger discursive strategies dominated by different types of framing and how this affects the scope of institutional performance and, ultimately, the evolution of institutional fields. I have also drawn attention to how such framing processes are implicated in recursive, multi-level dynamics that straddle the organisational and institutional field levels. 
Research adopting such a multi-level perspective may be a fruitful avenue for connecting broader, emerging research agendas in the management accounting and institutional theory literatures. On the one hand, institutional theorists have increasingly called for research that moves away from the predominant emphasis on institutional fields as the main unit of analysis and establishes an "outside-in" perspective on how field-level processes affect intraorganisational practices and processes (Greenwood et al. 2014, Meyer and Höllerer 2014). On the other hand, management accounting scholars using institutional theory have been urged to adopt a more pronounced, "inside-out" perspective to pay greater attention to how accounting practices are not only institutionalised in individual organisations but also implicated in the shaping of institutional fields (Dillard et al. 2004, Modell 2014). Institutional performance constitutes a useful bridging concept which may further rapprochement between these strands of research whilst rekindling the interest of institutional theorists in the somewhat neglected notion of performance as a key analytical category. Further research into this topic can create new points of connection between the accounting and management and organisation studies literatures and stimulate reciprocal exchange of ideas between these bodies of scholarship. However, much empirical work remains to be done to examine how institutional performance is constructed within and across institutional fields and how PMM practices are implicated in such processes. 


\section{References}

Adolfsson, P. and Wikström, E., 2007. After quantification: quality dialogue and performance. Financial Accountability and Management, 23 (1), 73-89.

Ansari, S., Wijen, F. and Gray, B., 2013. Constructing a climate change logic: an institutional perspective on the "tragedy of the commons". Organization Science, 24 (4), 1014-1040.

Arena, M. and Jeppesen, K.K., 2016. Practice variation in public sector internal audit: an institutional analysis. European Accounting Review, 25 (2), 319-345.

Arjaliès, D-L., 2010. A social movement perspective on finance: how socially responsible investment mattered. Journal of Business Ethics, 92 (1), 57-78.

Arnaboldi, M., and Azzone, G., 2010. Constructing performance measurement in the public sector. Critical Perspectives on Accounting, 21 (4), 266-282.

Battilana, J. and Dorado, S., 2010. Building sustainable hybrid organizations: the case of commercial microfinance organizations. Academy of Management Journal, 53 (6), 14191440 .

Beer, H.A. and Micheli, P., 2017. How performance measurement influences stakeholders in not-for-profit organizations. International Journal of Operations and Production Management, 37 (9), 1164-1184.

Benford, R.D. and Snow, D.A., 2000. Framing processes and social movements: an overview and assessment. Annual Review of Sociology, 26, 611-639.

Bhimani, A., Dai, N.T, Sivabalan, P. and Tang, G., 2018. How do enterprises respond to a managerial accounting performance measure mandated by the state? Journal of Management Accounting Research (in press).

Bitektine, A. and Haack, P., 2015. The "macro" and the "micro" of legitimacy: toward a multilevel theory of the legitimacy process. Academy of Management Review, 40 (1), 49-75.

Boitier, M. and Riviere, A. 2013. Freedom and responsibility for French universities: from global steering to local management. Accounting, Auditing and Accountability Journal, 26 (4), 616-649.

Brignall, S., and Modell, S., 2000. An institutional perspective on performance measurement and management in the "new public sector". Management Accounting Research, 11 (3), 281306.

Broadbent, J. and Laughlin, R., 2009. Performance management systems: a conceptual model. Management Accounting Research, 20 (4), 283-295.

Bromley, P. and Powell, W.W., 2012. From smoke and mirrors to walking the talk: decoupling in the contemporary world. Academy of Management Annals, 4, 483-530.

Burchell, S., Clubb, C., Hopwood, A., Hughes, J. and Nahapiet, J., 1980. The roles of accounting in organizations and society. Accounting, Organizations and Society, 5 (1), 5-27. 
Carlsson-Wall, M., Kraus, K. and Messner, M., 2016. Performance measurement systems and the enactment of different institutional logics: insights from a football organization/ Management Accounting Research, 32, 45-61.

Catasús, B., Ersson, S., Gröjer, J-E. and Wallentin, F.Y., 2007. What gets measured gets ... on indicating, mobilizing and acting, Accounting, Auditing and Accountability Journal, 20 (4), 505-522.

Catasús, B., and Grönlund, A., 2005. More peace for less money: measurement and accountability in the Swedish Armed Forces. Financial Accountability and Management, 21 (4), 467-484.

Chang, L-C., 2006. Managerial responses to externally imposed performance measurement in the NHS: an institutional theory perspective. Financial Accountability and Management, 22 (1), 63-85.

Chenhall, R.H., Hall, M. and Smith, D., 2013. Performance measurement, modes of evaluation and the development of compromising accounts. Accounting, Organizations and Society, 38 (4), 268-287.

Chiwamit, P., Modell, S. and Scapens, R.W., 2017. Regulation and adaptation of management accounting innovations: the case of Economic Value Added in Thai state-owned enterprises. Management Accounting Research, 37, 30-48.

Chiwamit, P., Modell, S. and Yang, C., 2014. The societal relevance of management accounting innovations: Economic Value Added and institutional work in the fields of Chinese and Thai state-owned enterprises. Accounting and Business Research, 44 (2), 144180 .

Chreim, S., 2006. Managerial frames and institutional discourses of change: employee appropriation and resistance. Organization Studies, 27 (9), 1261-1287.

Christiansen, L.H. and Lounsbury, M., 2013. Strange brew: bridging logics via institutional bricolage and the reconstitution of organizational identity, Research in the Sociology of Organizations, 39B, 199-232.

Cloutier, C. and Langley, A., 2013. The logic of institutional logics: insights from French pragmatist sociology. Journal of Management Inquiry, 22 (4), 360-380.

Conrad, L. and Uslu, P.G., 2012. UK health sector performance management: conflict, crisis and unintended consequences. Accounting Forum, 36 (4), 231-250.

Cooper, D.J. and Ezzamel, M., 2013. Globalization discourses and performance measurement in a multinational firm. Accounting, Organizations and Society, 38 (4), 288-313.

Cornelissen, J.P. and Werner, M.D., 2014. Putting framing in perspective: a review of framing and frame analysis across the management and organizational literature. Academy of Management Annals, 8, 181-235. 
Cuganesan, S. and Lacey, D., 2011. Developments in public sector performance measurement: a project on producing return on investment metrics for law enforcement. Financial Accountability and Management, 27 (4), 458-479.

Dai, N.T., Tan, Z.S., Tang, G. and Xiao, J.Z., 2017. IPOs, institutional complexity, and management accounting in hybrid organisations: a field study in a state-owned enterprise in China. Management Accounting Research, 36, 2-23.

David, R.J. and Bitektine, A.B., 2009. The deinstitutionalization of institutional theory? Exploring divergent agendas in institutional research. In: A. Buchanan and A. Bryman, eds. The SAGE Handbook of Organizational Research Methods, Thousand Oaks: Sage, 160-175.

Deephouse, D.L. and Suchman, M., 2008. Legitimacy in organizational institutionalism. In R. Greenwood, C. Oliver, K. Sahlin and R. Suddaby, eds. The SAGE Handbook of Organizational Institutionalism, Thousand Oaks: Sage, 49-77.

Déjean, F., Gond, P. and Leca, B., 2004. Measuring the unmeasured: an institutional entrepreneur strategy in an emerging industry. Human Relations, 57 (6), 741-764.

Dillard, J.F., Rigsby, J.T. and Goodman, C., 2004. The making and remaking of organization context: duality and the institutionalization process. Accounting, Auditing and Accountability Journal, 17 (4), 506-542.

DiMaggio, P.J. and Powell, W.W., 1983. The Iron Cage Revisited: Institutional Isomorphism in Organizational Fields. American Sociological Review, 48 (1), 147-160.

Edenius, M. and Hasselbladh, H., 2002. The balanced scorecard as an intellectual technology. Organization, 9 (2), 249-273.

Englund, H., Gerdin, J. and Abrahamsson, G., 2013. Accounting ambiguity and structural change. Accounting, Auditing and Accountability Journal, 26 (3), 423-448.

Espeland, W.N. and Sauder, M., 2007. Rankings and reactivity. How public measures recreate social worlds. American Journal of Sociology, 113 (1), 1-40.

Ezzamel, M., Robson, K. and Stapleton, P., 2012. The logics of budgeting: theorization and practice variations in the educational field. Accounting, Organizations and Society, 37 (4), 281-303.

Ezzamel, M., Willmott, H. and Worthington, F., 2008. Manufacturing shareholder value: the role of accounting in organizational transformation, Accounting, Organizations and Society, 33 (2), 107-140.

Ferreira, A. and Otley, D.T., 2009. The design and use of performance management systems: an extended framework for analysis. Management Accounting Research, 20 (4), 263-282.

Fiss, P.C. and Hirsch, P.M., 2005. The discourse of globalization: framing and sensemaking of an emerging concept. American Sociological Review, 70 (1), 29-52.

Fiss, P.C. and Zajac, E.J., 2006. The symbolic management of strategic change: sensegiving via framing and decoupling. Academy of Management Journal, 49 (6), 1173-1193. 
Franco-Santos, M., Lucianetti, L. and Bourne, M., 2012. Contemporary performance measurement systems: a review of their consequences and a framework for research. Management Accounting Research, 23 (2), 79-119.

Furnari, S., 2018. When does an issue trigger change in a field? A comparative approach to issue frames, field structures and types of field change. Human Relations, 71 (3), 321-348.

George, E., Chattopadhyay, P., Sitkin, S.B. and Barden, J., 2006. Cognitive underpinnings of institutional persistence and change: a framing perspective. Academy of Management Review, 31 (2), 347-365.

Giamporcaro, S. and Gond, J-P., 2016. Calculability as politics in the construction of markets: the case of socially responsible investment in France. Organization Studies, 37 (4), 465-495.

Goffman, E., 1974. Frame Analysis: An Essay on the Organization of Experience, $\left(2^{\text {nd }}\right.$ ed), Cambridge, MA:, Harvard University Press.

Goretzki, L., Mack, S., Messner, M. and Weber, J., 2018. Exploring the persuasiveness of accounting numbers in the framing of 'performance' - a micro-level analysis of performance review meetings. European Accounting Review, 27 (3), 495-525.

Gray, B. Purdy, J.M. and Ansari, S, 2015. From interaction to institutions: microprocesses of framing and mechanisms for the structuring of institutional fields. Academy of Management Review, 40 (1), 115-143.

Greenwood, R., Hinings, C.R and Whetten, D., 2014. Rethinking institutions and organizations. Journal of Management Studies, 51 (7), 1206-1220.

Greenwood, R., Raynard, M., Kodeih, F., Micelotta, A.R. and Lounsbury, M., 2011. Institutional complexity and organizational responses. Academy of Management Annals, 5, 317-371.

Greenwood, R. and Suddaby, R., 2006. Institutional entrepreneurship in mature fields: the big five accounting firms. Academy of Management Journal, 49 (1), 27-48.

Hall, M., Millo, Y. and Barman, E., 2015. Who and what really counts? Stakeholder prioritization and accounting for social value. Journal of Management Studies, 52 (7), 907934.

Hiebl, M.R.W., 2018. Management accounting as a political resource for enabling embedded agency. Management Accounting Research, 38, 22-38.

Hopper, T. and Major, M., 2007. Extending institutional analysis through theoretical triangulation: regulation and activity-based costing in Portuguese Telecommunications. European Accounting Review, 16 (1), 59-97.

Hopwood, A.G. and Miller, P., eds, 1994. Accounting as Social and Institutional Practice, Cambridge: Cambridge University Press. 
Ittner, C.D. and Larcker, D.F., 1998. Innovation in performance measurement: trends and research implications. Journal of Management Accounting Research, 10, 205-238.

Jonsson, S. and Lounsbury, M., 2017. The meaning of economic democracy: institutional logics, parabiosis, and the construction of frames. Research in the Sociology of Organizations, 48A, 71-99.

Kaplan, S., 2008. Framing contests: strategy making under uncertainty. Organization Science, 19 (5), 729-752.

Kelly, R., Doyle, G and O'Donohue, S., 2015. Framing performance management of acutecare hospitals by interlacing NPM and institutional perspectives: a new theoretical framework. Financial Accountability and Management, 31 (1), 69-91.

Kondra, A.Z and Hinings, C.R., 1998. Organizational diversity and change in institutional theory. Organization Studies, 19 (5), 743-767.

Kornberger, M. and Carter, C., 2010. Manufacturing competition: how accounting practices shape strategy making in cities. Accounting, Auditing and Accountability Journal, 23 (3), 325-349.

Kraatz, M.S. and Block, E., 2008. Organizational implications of institutional pluralism. In R. Greenwood, C. Oliver, K. Sahlin and R. Suddaby, eds. The Sage Handbook of Organizational Institutionalism.Thousand Oaks: Sage, 243-275.

Kraus, K. and Strömsten, T., 2012. Going public: The role of accounting and shareholder value in making sense of an IPO. Management Accounting Research, 23 (3), 186-201.

Lander, M.W., Koene, B.A.S. and Linssen, S.N., 2013. Committed to professionalism: organizational responses of mid-tier accounting firms to conflicting institutional logics. Accounting, Organizations and Society, 38 (2), 130-148.

Länsiluoto, A., Järvenpää, M. and Krumwiede, K., 2013. Conflicting interests but filtered targets: stakeholder and resource-dependency analyses at a University of Applied Sciences. Management Accounting, Research, 24 (4), 228-245.

Le Theule, M-A. and Lupu, I., 2016. Publishing without editors or authors? Competing logics, circulation, and cultural creation in a publishing firm. Critical Perspectives on Accounting, 38, 14-33.

Ligonie, M., 2018. The "forced performativity" of a strategy concept: exploring how shared value shaped a gambling company's strategy. Long Range Planning (in press).

Llewellyn, S. and Northcott, D., 2005. The average hospital. Accounting, Organizations and Society, 30 (6), 555-583. 
Lockett, A., Wright, M. and Wild, A., 2015. The institutionalization of third stream activities in UK higher education: the role of discourse and metrics. British Journal of Management, 26 (1), 78-92.

Lok, J., 2018. Why (and how) institutional theory can be critical: addressing the challenge to institutional theory's critical turn. Journal of Management Inquiry (in press).

Lorino, P., Mourey, D. and Schmidt, G., 2017. Goffman's theory of frames and situated meaning-making in performance reviews. The case of a category management approach in the French retail sector. Accounting, Organizations and Society, 58, 32-49.

Lounsbury, M., 2007. A tale of two cities: competing logics and practice variation in the professionalizing of mutual funds. Academy of Management Journal, 50 (2), 289-307.

Lounsbury, M., 2008. Institutional rationality and practice variation: new directions in the institutional analysis of practice. Accounting, Organizations and Society, 33 (4-5), 349-361.

Lounsbury, M. and Ventresca, M., 2003. The new structuralism in organizational theory. Organization, 10 (3), 457-480.

Lounsbury, M., Ventresca, M. and Hirsch, P.M., 2003. Social movements, field frames and industry emergence: a cultural-political perspective on US recycling, Socio-Economic Review, 1 (1), 71-104.

McAdam, D, and Scott, W.R., 2005. Organizations and movements. In G.F. Davis, D. McAdam, W.R. Scott and M.N. Zald, M.N., eds. Social Movements and Organization Theory, Cambridge: Cambridge University Press, 4-40.

Meyer, J.W. and Rowan, B., 1977. Institutionalized organizations: formal structure as myth and ceremony. American Journal of Sociology, 83 (2), 440-463.

Meyer, M.W. and Zucker, L.G., 1989. Permanently Failing Organizations. Newbury Park: Sage.

Meyer, R.E. and Höllerer, M.A, 2010. Meaning structures in a contested issue field: a topographic map of shareholder value in Austria. Academy of Management Journal, 53 (6), 1241-1262.

Meyer, R.E. and Höllerer, M.A., 2014. Does institutional theory need redirecting? Journal of Management Studies, 51 (7), 1221-1233.

Micelotta, E., Lounsbury, M. and Greenwood, R., 2017. Pathways of institutional change: an integrative review and research agenda. Journal of Management, 43 (6), 1885-1910.

Miller, P. and Power, M., 2013. Accounting, organizing and economizing: connecting accounting research and organization theory. Academy of Management Annals, 7, 555-603. 
Modell, S., 2001. Performance measurement and institutional processes: a study of managerial responses to public sector reform. Management Accounting Research, 12 (4), 437-464.

Modell, S., 2003. Goals versus institutions: the development of performance measurement in the Swedish university sector, Management Accounting Research, 14 (4), 333-359.

Modell, S., 2004. Performance measurement myths in the public sector: A research note. Financial Accountability and Management, 20 (1), 39-55.

Modell, S., 2005. Students as consumers? An institutional field-level analysis of the construction of performance measurement practices. Accounting, Auditing and Accountability Journal, 18 (4), 537-563.

Modell, S., 2009. Institutional research on performance measurement and management in the public sector accounting literature: a review and assessment. Financial Accountability and Management, 25 (3), 277-303.

Modell, S., 2012. Strategy, political regulation and management control in the public sector: institutional and critical perspectives. Management Accounting Research, 23 (4), 278-295.

Modell, S., 2014. The societal relevance of management accounting: an introduction to the special issue. Accounting and Business Research, 44 (2), 83-103.

Modell, S. 2015. Making institutional accounting research critical: dead end or new beginning? Accounting, Auditing and Accountability Journal, 28 (5), 773-808.

Modell, S., Jacobs, K. and Wiesel, F., 2007. A process (re)turn? Path dependencies, institutions and performance management in Swedish central government. Management Accounting Research, 18 (4), 453-475.

Modell, S. and Wiesel, F., 2008. Marketization and performance measurement in Swedish central government: a comparative institutionalist study, Abacus, 44 (3), 251-283.

Modell, S. and Yang, C., 2018. Financialisation as a strategic action field: an historically informed field study of governance reforms in Chinese state-owned enterprises, Critical Perspectives on Accounting (in press).

Moore, D.R.J., 2013. Sustainability, institutionalization and the duality of structure: contradiction and unintended consequences in the political context of an Australian water business. Management Accounting Research, 24 (4), 366-386.

Oliver, C., 1991. Strategic responses to institutional processes, Academy of Management Review, 16 (1), 145-179.

Østergren, K., 2006. The institutional construction of consumerism: a study of implementing quality indicators. Financial Accountability and Management, 22 (2), 179-205. 
Pache, A-C. and Santos, F., 2013. Inside the hybrid organization: selective coupling as a response to competing institutional logics. Academy of Management Journal, 56 (4), 9721001.

Pollock, N., D’Adderio, L., Williams, R. and Leforestier, L., 2018. Conforming or transforming? How organizations respond to multiple rankings. Accounting, Organizations and Society, 64, 55-68.

Polzer, T., Meyer, R.E., Höllerer, M. and Seiwald, J., 2017. Institutional hybridity in public sector reform: replacement, blending, or layering of administrative problems. Research in the Sociology of Organizations, 48B, 69-99.

Powell, W.W., 1988. Institutional effects on organizational structure and performance. In L.G. Zucker, ed. Institutional Patterns and Organizations: Culture and Environment. Cambridge MA: Ballinger, 115-136.

Power, M., 2015. How accounting begins: object formation and the accretion of infrastructure. Accounting, Organizations and Society, 47, 43-55.

Purdy, J., Ansari, S. and Gray, B., 2018. Are logics enough? Framing as an alternative tool for understanding institutional meaning making. Journal of Management Inquiry (in press).

Purdy, J.M. and Gray, B., 2009. Conflicting logics, mechanisms of diffusion, and multilevel dynamics in emerging institutional fields. Academy of Management Journal, 52 (2), 355-380.

Qu, S. and Cooper, D.J., 2011. The role of inscriptions in producing a balanced scorecard. Accounting, Organizations and Society, 36 (6), 344-362.

Rautiainen, A., 2010. Contending legitimations: performance measurement coupling and decoupling in two Finnish cities. Accounting, Auditing and Accountability Journal, 23 (3), 373-391.

Rautiainen, A. and Järvenpää, M., 2012. Institutional logics and responses to performance measurement systems. Financial Accountability and Management, 28 (2), 164-188.

Rautiainen, A., Urquia-Grande, E. and Munoz-Colomina, C., 2017. Institutional logics in police performance indicator development: a comparative case study of Spain and Finland. European Accounting Review, 26 (2), 165-191.

Reay, T. and Hinings, C.R., 2005. The recomposition of organizational fields: health care in Alberta. Organization Studies, 26 (3), 351-384.

Reay, T. and Hinings, C.R., 2009. Managing the rivalry of competing institutional logics. Organization Studies, 30 (6), 629-652.

Schäffer, U., Strauss, E. and Zecher, C. (2015) The role of management control systems in situations of institutional complexity, Qualitative Research in Accounting and Management, 12 (4), 395-424. 
Schneiberg, M., 2007. What's on the path? Path dependence, organizational diversity and the problem of institutional change in the US economy, 1900-1950. Socio-Economic Review, 5 (1), 47-80.

Scott, W.R., 1987. The adolescence of institutional theory. Administrative Science Quarterly, 32 (4), 493-511.

Scott, W.R., Ruef, M., Mendel, P. and Caronna, C., 2000. Institutional Change and Healthcare Organizations: From Professional Dominance to Managed Care, Chicago: Chicago University Press.

Seo, M-G. and Creed, W.E.D. 2002. Institutional contradictions, praxis, and institutional change: a dialectical perspective. Academy of Management Review, 27 (2), 222-247.

Sharma, U, Lawrence, S. and Lowe, A., 2010. Institutional contradiction and management control innovation: a field study of total quality management practices in a privatized telecommunication company. Management Accounting Research, 21 (4), 251-264.

Siti-Nabiha, A.K. and Scapens, R.W., 2005. Stability and change: an institutionalist study of management accounting change. Accounting, Auditing and Accountability Journal, 18 (1), 44-73.

Smets, M, Morris, T. and Greenwood, R., 2012. From practice to field: a multilevel model of practice-driven institutional change. Academy of Management Journal, 55 (4), 877-904.

Snow, D.A., Rochford, E.B., Worden, S.K. and Benford, R.D., 1986. Frame alignment processes, micromobilization, and movement participation. American Sociological Review, $51,464-481$.

Sundin, H., Granlund, M. and Brown, D.A., 2010. Balancing multiple competing objectives with a balanced scorecard. European Accounting Review, 19 (2), 203-246.

Sutheewasinnon, P., Hoque, Z. and Nyamori, R.O., 2016. Development of a performance management system in the Thailand public sector: isomorphism and the role and strategies of institutional entrepreneurs. Critical Perspectives on Accounting, 40, 26-44.

ter Bogt, H., van Helden, G.J. and van der Kolk, B., 2015. Challenging the NPM ideas about performance management: selectivity and differentiation in outcome-oriented performance budgeting. Financial Accountability and Management, 31 (3), 287-315.

Thornton, P.H., 2004. Markets from Culture: Institutional Logics and Organizational Decisions in Higher Education Publishing, Stanford: Stanford University Press.

Thornton, P.H., Jones, C. and Kury, K., 2005. Institutional logics and institutional change in organizations: transformation in accounting, architecture, and publishing. Research in the Sociology of Organizations, 23, 125-170.

Townley, B., Cooper, D.J. and Oakes, L., 2003. Performance measures and the rationalization of organizations, Organization Studies, 24 (7), 1045-1071. 
van Hengel, H., Budding, T. and Groot, T., 2014. Loosely coupled results control in Dutch municipalities. Financial Accountability and Management, 30 (1), 49-74.

Vermeulen, P.A.M., Zietsma, C., Greenwood, R. and Langley, A., 2016. Strategic responses to institutional complexity. Strategic Organization, 14 (4), 277-286.

Watkins, A.L. and Arrington, C.E., 2007. Accounting, new public management and American politics: theoretical insights into the National Performance Review, Critical Perspectives on Accounting, 18 (1), 33-58.

Werner, M.D. and Cornelissen, J.P., 2014. Framing the change: switching and blending frames and their role in instigating institutional change. Organization Studies, 35 (10), 14491472 .

Wiesel, F. and Modell, S., 2014. From New Public Management to New Public Governance? Hybridization and implications for public sector consumerism. Financial Accountability and Management, 30 (2), 175-205.

Wooten, M. and Hoffman, A.J., 2008. Organizational fields: past, present and future. In R. Greenwood, C. Oliver, K. Sahlin and R. Suddaby, eds. The Sage Handbook of Organizational Institutionalism. Thousand Oaks: Sage, 130-147.

Yang, C. and Modell, S., 2013. Power and performance: institutional embeddedness and performance management in a Chinese local government organization. Accounting, Auditing and Accountability Journal, 26 (1), 101-132.

Yang, C. and Modell, S., 2015. Shareholder orientation and the framing of management control practices: a field study in a Chinese state-owned enterprise. Accounting, Organizations and Society, 45, 1-23.

Zald, M.N. and Lounsbury, M., 2010. The wizards of Oz: towards an institutional approach to elites, expertise and command posts. Organization Studies, 31 (7), 963-996.

Zilber, T., 2013. Institutional logics and institutional work: should they be agreed? Research in the Sociology of Organizations, 39A, 77-96.

Zilber, T., 2017. How institutional logics matter: a bottom-up approach. Research in the Sociology of Organizations, 48A, 137-155. 


\section{Appendix. Examples of research questions for operationalising the propositions in empirical} research.

\begin{tabular}{|c|c|}
\hline Proposition & Research questions \\
\hline $\begin{array}{l}\text { P1: The higher the level of institutional complexity } \\
\text { due to heterogeneous and competing constituency } \\
\text { demands in an institutional field, the greater the use of } \\
\text { contradictory PMM practices in organisations within } \\
\text { that field. }\end{array}$ & $\begin{array}{l}\text { - Which constituency demands matter in } \\
\text { institutional fields? } \\
\text { - Are these constituency demands consistent or } \\
\text { do they conflict with each other? } \\
\text { - How do the demands of various } \\
\text { constituencies affect the use of organisational } \\
\text { goals and performance metrics? } \\
\text { - What are the relationships between these } \\
\text { goals and performance metrics? }\end{array}$ \\
\hline $\begin{array}{l}\text { P2a: In organisations pursuing radical change, } \\
\text { contradictory PMM practices will promote discursive } \\
\text { strategies dominated by frame shifting insofar as the } \\
\text { conception of performance is concerned. }\end{array}$ & $\begin{array}{l}\text { To what extent do organisational actors use } \\
\text { conflicting goals and performance metrics to } \\
\text { justify radical organisational change? } \\
\text { To what extent do justifications for radical } \\
\text { organisational change entail attempts to } \\
\text { replace the meanings attributed to notions of } \\
\text { organisational performance with new } \\
\text { meanings? }\end{array}$ \\
\hline $\begin{array}{l}\text { P2b: Strategies of frame shifting, engendering radical } \\
\text { change in organisations and institutional fields, will } \\
\text { construct institutional performance in narrow terms. }\end{array}$ & $\begin{array}{l}\text { Do change initiatives aimed at radically } \\
\text { changing the meanings attributed to notions } \\
\text { of organisational performance gain traction in } \\
\text { organisations and institutional fields? } \\
\text { What impact do such change initiatives have } \\
\text { on the scope of the conceptions of } \\
\text { performance that come to matter in } \\
\text { institutional fields? }\end{array}$ \\
\hline $\begin{array}{l}\text { P3a: In organisations pursuing moderate change, } \\
\text { contradictory PMM practices will promote discursive } \\
\text { strategies dominated by frame blending insofar as the } \\
\text { conception of performance is concerned. }\end{array}$ & $\begin{array}{l}\text { To what extent do organisational actors try to } \\
\text { reconcile tensions between conflicting goals } \\
\text { and performance metrics whilst pursuing a } \\
\text { degree of organisational change? } \\
\text { To what extent do such attempts to reconcile } \\
\text { tensions entail efforts to advance new, hybrid } \\
\text { notions of organisational performance? }\end{array}$ \\
\hline $\begin{array}{l}\text { P3b: Strategies of frame blending, engendering } \\
\text { moderate change in organisations and institutional } \\
\text { fields, will construct institutional performance in } \\
\text { broad terms. }\end{array}$ & $\begin{array}{l}\text { Do change initiatives aimed at advancing } \\
\text { new, hybrid notions of organisational } \\
\text { performance gain traction in organisations } \\
\text { and institutional fields? } \\
\text { What impact do such change initiatives have } \\
\text { on the scope of the conceptions of } \\
\text { performance that come to matter in } \\
\text { institutional fields? }\end{array}$ \\
\hline $\begin{array}{l}\text { P4a: In organisations seeking to maintain stability, } \\
\text { contradictory PMM practices will promote discursive } \\
\text { strategies dominated by frame decoupling insofar as } \\
\text { the conception of performance is concerned. }\end{array}$ & $\begin{array}{l}\text { To what extent do organisational actors try to } \\
\text { avoid tensions related to conflicting goals and } \\
\text { performance metrics in an attempt to } \\
\text { maintain organisational stability? } \\
\text { - To what extent do such attempts to avoid } \\
\text { tensions entail efforts to separate diverse }\end{array}$ \\
\hline
\end{tabular}




\begin{tabular}{|l|ll|}
\hline & & notions of organisational performance? \\
\hline $\begin{array}{l}\text { P4b: Strategies of frame decoupling, inducing stability } \\
\text { in organisations and institutional fields, will construct } \\
\text { institutional performance in broad terms. }\end{array}$ & $\begin{array}{l}\text { Do the efforts to separate diverse notions of } \\
\text { organisational performance gain acceptance } \\
\text { and preserve stability in organisations and } \\
\text { institutional fields? }\end{array}$ \\
& $\begin{array}{l}\text { What impact do such efforts to maintain } \\
\text { stability have on the scope of the conceptions } \\
\text { of performance that come to matter in } \\
\text { institutional fields? }\end{array}$ \\
\hline $\begin{array}{l}\text { P5: The broader the scope of institutional } \\
\text { performance, the higher the level of institutional } \\
\text { complexity due to heterogeneous and competing } \\
\text { constituency demands in institutional fields. }\end{array}$ & $\begin{array}{l}\text { Do broader and narrower conceptions of } \\
\text { performance appeal to diverse constituencies } \\
\text { in institutional fields? } \\
\text { Does the use of such conceptions of } \\
\text { performance change or preserve the relative } \\
\text { salience of various constituency demands? }\end{array}$ \\
\hline
\end{tabular}




\section{Revision Notes}

In response to the feedback provided by the Editor, I have made a number of changes to the manuscript.

To better spell out the key message at an early stage, I revised the two opening paragraphs slightly and then developed a new paragraph that makes the intended contribution a bit more explicit (p. 3). As I try to explain in this paragraph, I partly see this paper as an attempt to bridge the divide between the accounting and more general management/organisation studies literatures insofar as the issues of performance measurement and management are concerned whilst opening up new perspectives on these issues in relation to prior institutional research. I hope this sets out the research agenda I am trying to develop a bit more clearly. Following on from these revisions, I also made some minor revisions to various parts of the Discussion and Concluding Remarks sections where the general contributions to institutional theory and management/organisation studies are outlined.

As requested by the Editor, I have made a number of clarifications to the paragraphs outlining the three types of framing of interest in the paper (pp. 7-9). I have also developed a paragraph summarising key points related to how the three types of framing relate to institutional change and stability, which serves as a bridge over to the ensuing discussion of the framing of institutional performance (p. 9).

I have also tried to enhance the readability of the paper. Where possible, I have tried to shorten some paragraphs and divide longer paragraphs into two. However, this was not always feasible without breaking the flow of the line of argument, so I have retained some paragraphs that the Editor seemed to think were a bit long while trying to ensure that they are as concise as possible. For further details about the actions to enhance the readability, see comments in response to the reviewer below.

Following the advice of the Editor, I made the following revisions to address specific points raised by the reviewer:

\begin{tabular}{|l|l|}
\hline Reviewer comments & My response/actions \\
\hline $\begin{array}{l}\text { First, the paper is intellectually demanding. } \\
\text { Although is it not an issue per se, I wonder to } \\
\text { which extent you could simplify a bit the } \\
\text { wording (and the jargon) to make it more } \\
\text { reader friendly. }\end{array}$ & $\begin{array}{l}\text { I have gone through the paper carefully and } \\
\text { have revised a number of sentences which } \\
\text { were perhaps a bit hard to read. I have also } \\
\text { double-checked the manuscript to ensure that } \\
\text { the use of key conceptual terms is consistent } \\
\text { throughout without containing too much, } \\
\text { unnecessary "jargon" (although an element of } \\
\text { this is probably inevitable in a conceptual } \\
\text { paper like this one that builds on a well- } \\
\text { established, theoretical foundation with its } \\
\text { own, specific terminology). }\end{array}$ \\
\hline $\begin{array}{l}\text { Second, you could think of a better (and } \\
\text { more impactful) title. The first part of it }\end{array}$ & $\begin{array}{l}\text { I have revised the title so that it now reads } \\
\text { "Constructing institutional performance: a }\end{array}$ \\
\hline
\end{tabular}




\begin{tabular}{|c|c|}
\hline $\begin{array}{l}\text { currently doesn't add anything. I would go } \\
\text { either for a shorter title (i.e., "Towards a } \\
\text { Social Framing Perspective on Performance } \\
\text { Measurement and Management") or a more } \\
\text { ambitious one (i.e.: "Rethinking..."; } \\
\text { "Opening..."; "Theorizing...; etc.). }\end{array}$ & $\begin{array}{l}\text { multi-level framing perspective on } \\
\text { performance measurement and } \\
\text { management". I feel this title provides a more } \\
\text { precise indication of the main ideas in the } \\
\text { paper and makes explicit reference to the key } \\
\text { concepts being mobilised. }\end{array}$ \\
\hline $\begin{array}{l}\text { Third, to maximize the impact of the paper, I } \\
\text { wonder if you could add a table at the end } \\
\text { where for each proposition you would write a } \\
\text { series of empirical research questions ( } 4 / 5 \\
\text { questions per proposition). I think it could } \\
\text { help formalize the research agenda emerging } \\
\text { from the paper and further stimulate readers' } \\
\text { imagination. }\end{array}$ & $\begin{array}{l}\text { I have developed a set of general research } \\
\text { questions that will hopefully help other } \\
\text { researchers operationalise the propositions. I } \\
\text { make some brief references to this in the } \\
\text { body of the text (p. 24). However, since this } \\
\text { goes a little bit beyond the key contents of } \\
\text { the paper (and is a bit unusual for a } \\
\text { conceptual paper like this one), I decided to } \\
\text { put these questions in an appendix. }\end{array}$ \\
\hline
\end{tabular}

